\title{
Estimation of Extreme Wave and Wind Design Parameters for Offshore Wind Turbines in Gulf of Maine Using a POT Method January $23^{\text {rd }}, 2014$ \\ Revision 2
}

1. Anthony Viselli, PE, PhD, Research Engineer, University of Maine 5793 AEWC Orono, ME 04401, USA. anthony.viselli@maine.edu. Phone: 1-207-581-2828. Fax: 207-581-2074, Corresponding Author

2. George Z. Forristall, PhD, Principal Engineer, Forristall Ocean Engineering, 101 Chestnut Camden, ME 04843, USA. 1-207-236-7747

3. Bryan R. Pearce, PhD, PE, Professor Emeritus, Department of Civil/ Environmental Engineering, University of Maine, 5711 Boardman Hall, Orono, ME 04469-5711. 1-207-581-1216

4. Habib J. Dagher, PhD, PE, Professor, Department of Civil/ Environmental Engineering, University of Maine, 5793 AEWC, Orono, ME 04469-5711. 1-207-581-2138

\section{Acronyms, Symbols, and Abbreviations:}

$\mathrm{ABS}=$ American Bureau of Shipping

ASCE $=$ American Society of Civil Engineers

GoM $=$ Gulf of Maine

GP $=$ Generalized Pareto

$\mathrm{H}_{\mathrm{s}}=$ significant wave height

IEC = Internationale Electrotechnical Commission

ISO = International Standards Organization

NERACOOS $=$ North-eastern Regional Association of Coastal and Ocean Observing Systems

NOAA $=$ National Oceanic and Atmospheric Administration

NREL = National Renewable Energy Laboratory

POT $=$ peaks over a threshold

th $=$ threshold used for POT analysis

$\mathrm{T}_{\mathrm{p}}=$ wave peak spectral period 
15 UMaine $=$ University of Maine

$16 \quad$ US $=$ United States

$17 \quad \mathrm{~V}=$ wind speed

$18 \quad \mathrm{~V}_{\text {ref }}=$ wind speed at sensor height

$19 \quad \mathrm{~V}_{\mathrm{z}}=$ wind speed at height $\mathrm{z}$

$20 \mathrm{w}=$ time window

$21 \quad \mathrm{Z}=$ height above sea level

$22 \quad \mathrm{z}_{\text {ref }}=$ referenced sensor height above sea level

$23 \alpha=$ wind shear power law exponent

$24 \mathrm{k}=$ number of standard deviations above mean value

$25 \mu=$ mean 


\section{Introduction}

Offshore wind turbines in the Gulf of Maine (GoM) offer important advantages as a source of abundant and steady wind in close proximity to dense New England population centres while reducing land use issues encountered by land-based wind. The US Department of Energy's National Renewable Energy Laboratory (NREL) has identified the Gulf of Maine as having Class 6 and 7 winds and an estimated $157 \mathrm{GW}$ of wind power available within $95 \mathrm{~km}$ of the coast (Musial \& Ram, 2010).

Extreme environmental conditions such as significant wave height with mean associated peak period and wind speeds are required for design of offshore wind turbine support structures. There are no buoy data based estimates of these conditions available for the GoM. To that end, predictions of extreme design conditions for five sites in the GoM based on buoy data collected by the University of Maine (UMaine) and the National Oceanic and Atmospheric Administration (NOAA) are presented. Calculations include extreme waves with mean associated wave peak periods, 8-minute average wind speeds and 5-second average gust wind speeds. Extreme significant wave height results are compared to predictions made in past studies. Extreme wind speed values are compared to the American Society of Civil Engineers (ASCE, 2010) 3-second average gust wind speeds for on land coastal structures. In addition, wind shear coefficients and gust factors are estimated and compared to the ASCE (2010) estimates.

\section{Material and methods}

\subsection{Buoy Data}

The data were obtained from two sources: (1) UMaine manufactured and operated buoys deployed over the past ten years which are part of the North-Eastern Regional Association of Coastal and Ocean Observing Systems (NERACOOS) (Pettigrew, Wallinga, Neville, \& Schlenker, 2005) (UMaine, 2009) and (2) NOAA Buoys, operated by the National Data Buoy Centre with over twenty years of data (NOAA, 2011). The locations of buoys used as data sources are shown in Figure 1 and listed in Table 1. All buoys measured significant wave height, wave peak period, 8-minute average and 5-second average gust wind speeds at four or five meters above sea level. Data can be downloaded from appropriate online sites found within the reference section. Statistical parameters for the buoy wave and data sets are provided in Table 2. The mean significant wave height from the buoy data ranges from $0.6 \mathrm{~m}$ to $1.6 \mathrm{~m}$ and the mean for 8 -minute average wind speed at $4 \mathrm{~m}$ above sea level range from $4.7 \mathrm{~m} / \mathrm{s}$ to $6.6 \mathrm{~m} / \mathrm{s}$. The standard deviation, skewness, and kurtosis of each of these data sets are also provided. Some of the buoy data 
records are short (e.g. seven years) and extrapolating using this data can present uncertainty for long return period estimates. However, no other buoy data is available for this region at this time and there is a need for these estimates immediately.

\subsection{Extreme Value Analysis Methods}

Two methods were used to estimate extreme significant wave heights and wind speeds. The first method fits a Gumbel Distribution to all of the data collected or daily, weekly, monthly or yearly maxima. This method is called the "historical method" by ISO (2005) and it is often used to predict extreme significant wave heights. The second method fits a Generalized Pareto Distribution to Peaks over a Threshold (POT). The POT method is a more recent approach and employs techniques to identify and select non-serially correlated data points. Both methods were used to provide alternative ways of analysing the data and are compared in this study. Given, the increased ability to identify non-serial correlated data points, the POT method is the preferred method and is recommended for design.

The historical analysis is well known and was performed following the methodology of Sorenson (1993) with a Gumbel Distribution (Gumbel, 1958). The Gumbel distribution has been widely applied to the estimation of extreme wind speeds and significant wave heights (Castillo, 1988). With this method, there is not a clear rationale for choosing independent data points. The wind industry often uses only the annual maxima (Gross J. L. et al., 1995). Similarly, Coles (2001) used only annual maxima and fitted them to the Generalized Extreme Value Distribution (GEV). Including only annual maxima leaves little data for fitting to statistical models. Burton et al. (2001) found that there are about 160 independent extreme values per year for waves. We analysed data sets that include: all of the recorded buoy data (one or two samples every hour), daily maxima, weekly maxima, monthly maxima, and annual maxima. This provided a way to disaggregate the data from correlated weather patterns. The data set which produced the best fit was determined from a least squares linear regression analysis of the reduced variate data. There are five buoys each with a wave data set and wind speed data set. Each data set was investigated using all of the recorded buoy data (one or two samples every hour), daily maxima, weekly maxima, monthly maxima, and annual maxima resulting in fifty different $\mathrm{R}^{2}$ values computed (5bouys $\mathrm{x}$ 2data channelsx5maxima types). Figure 2 shows an example reduced variate plot for Buoy E01 significant wave height data that gave the best fit ( $\mathrm{R}^{2}$ value) using a plot of reduced variate and significant wave height, Hs. This particular fit used all of the data. 
The second extreme value method was a POT analysis following well known methods (Davison, A. C., and Smith, R. L., 1990; Mathiesen et al., 1994; Ferreira, J. A. and Soares, C. G., 1998). As stated by Tucker and Pitt (2001), this method involves selecting a threshold value and fitting a distribution to the data points. In this paper, the Generalized Pareto Distribution (GPD) was used. Figure 3 illustrates the POT peak selection process used in this study. Data points selected for use in fitting to the GPD function are shown in green. The dark dashed horizontal line is the threshold. The highest peaks over the threshold in the time period marked by the triangles were selected. The steps used in this process can be summarized as:

1. Identify all data above the threshold.

2. Loop through the data above the threshold in steps equal to a specified time window.

3. Select one max for each time window.

4. Check to make sure the maximum selected in each time window did not occur within one half of the time window of the previous data point selected. If the data point is within this duration, the point is considered to be serially related and discarded. The next highest data point that exceeded the threshold and does not lie within one half of time window is then selected.

5. The GPD is then fitted using the MATLAB function gpfit (MathWorks, 2011).

This POT analysis follows a process very similar to the work of Simiu (2011) and attempts to deal with sampling discrete maximum significant wave heights by selecting only significant wave heights above a specified threshold for a selected time window. Four, eight, twelve, and sixteen day time windows were considered. Similar techniques for identifying discrete storm or weather events have been employed by many such as Gibson et al. (2009).

Comparisons between the fits for different thresholds and time windows were made and a distribution was selected for prediction of extreme events. To select the appropriate threshold and time window, a sensitivity analysis was completed to study their effects on the extreme value analysis predictions. A sample case is now discussed. Figure 4 (a) shows sample results from a sensitivity study for buoy E01 showing the effects of time window duration and threshold selection on 100 year significant wave height predictions. Differences of up to a meter in significant wave height predictions were seen. The four time window traces agree well for low and high thresholds because this results in sampling very similar data sets. However, the low threshold predictions are based on many nonindependent data points resulting in a heterogeneous data set which is difficult to fit to statistical distributions as expressed by Ragan and Manuel (2008) and Toft et al. (2011). These authors further recommend choosing as high a 
threshold as possible. Thresholds greater than mean of the data plus 1.4 or 1.9 times the standard deviation or higher are recommended with the condition that there be enough data points to avoid sampling error. Naess similarly notes that only peaks over high thresholds are relevant for an extreme value analysis (1984). For Buoy E01, the significant wave height mean is $1.2 \mathrm{~m}$ and the standard deviation $0.8 \mathrm{~m}$. Therefore, the two recommended minimum thresholds would be greater than $2.3 \mathrm{~m}$ and $2.6 \mathrm{~m}$. For Buoy E01 a threshold of $3 \mathrm{~m}$ was selected as it exceed these recommended targets and still provided sufficient data for fitting the GPD. The effect of time window duration is now examined. In general, a larger time window is preferred to remove the effects of serial correlation. However, larger time windows result in fewer data points. For this particular buoy with a seven year data record, the 4-day time window was selected in lieu of the 8,12, and 16-day time windows. The 16 and 12-day windows generate too few data points for fitting the GPD. The 4-day time window provides a superior fit to the data as compared to the 8-day time window as evidenced by the individual fits of the GPD as shown in Figure 4 (b) and (c). Figure 4 (b) shows the selected fit for buoy E01 extreme significant wave height with a 4-day time window and a $3 \mathrm{~m}$ threshold. Figure 4 (c) shows the fit with an 8-day time window and a 3m threshold. Figure 4 (b) provides more data, provided a tighter confidence window, and was selected for use. Similar examinations of the data were performed for the other buoys.

\subsection{Mean Period Associated with Extreme Significant Wave Heights}

The mean peak periods associated with the predicted extreme significant wave heights were estimated using a scatter plot of measured peak period versus significant wave height for each buoy. A sample scatter diagram is presented in Figure 5 for the UMaine Buoy E01. The wave peak period data provided from the buoys is based on a fairly coarse spectral analysis. The resolution is a trade off with sampling variability of the spectral estimates. Raw buoy spectral data was not available for this study. To address this coarseness, a block average of the peak period was made using a significant wave height bin of $0.2 \mathrm{~m}$. A three-parameter power law fit was made to the block average data to predict the peak period associated with a given significant wave height.

\subsection{Wind Design Parameters}

The wind turbine industry requires several key design parameters. Preliminary estimates are made for these parameters. Due to differences in measurement conventions between the buoy instrumentations systems and standard wind engineering practices, corrections are required. Annual average power law wind shear exponents for 
each buoy were estimated from the 8-minute average buoy wind speed data and published 10-minute wind speed data at $90 \mathrm{~m}$ above sea-level from NREL. A power law wind shear model is recommended in the primary wind design standard, International Eletrotechnical Commission 61400-3 (2009). To calculate the power law wind shear exponent, a correction is needed to match the time averaging periods. IEC 61400-3 does not provide a general method for converting from one averaging period to another. The 8-minute average wind speed measured by the buoy was first converted to match the NREL reported 10-minute wind speeds with guidance from ISO 19901-1 (2005). Following ISO guidance, to convert from eight-minute wind speeds to 10-minute wind speeds, one must multiply the 8-minute wind speed by a factor of 0.99 . The power law wind shear exponent is $\alpha$ in equation (1).

$$
V_{z}=V_{\text {ref }}\left(\frac{z}{z_{r e f}}\right)^{\alpha}
$$

where $\mathrm{V}_{\mathrm{z}}$ is the wind speed at the desired height, $\mathrm{V}_{\text {ref }}$ is the known wind speed at the buoy sensor height, $\mathrm{z}$ is the height of interest, $z_{\text {ref }}$ is the height of the buoy measurement above sea level. The annual average wind shear power law exponent was estimated for each site by solving equation (1) for $\alpha$ using the annual mean of the 10-minute wind speed calculated from the buoy data for $\mathrm{V}_{\text {ref }}$ at $4 \mathrm{~m}$ and the annual mean $90 \mathrm{~m} 10$-minute wind speed published by the NREL (2010) for $\mathrm{V}_{\mathrm{z}}$. NREL developed these estimates for Maine using best practices for modelling offshore wind. The NREL Maine wind models have been validated against ocean buoys, marine automated stations, Coast Guard stations, lighthouses, and satellite-derived wind speeds $10 \mathrm{~m}$ over the ocean. In addition to wind shear exponents, the mean wind speed characteristics at each buoy were calculated at the sensor height and $90 \mathrm{~m}$ using the new wind shear power law exponent. The annual mean gust factor near sea level was also calculated by dividing the annual mean gust wind speed by the annual mean 8-minute average wind speed.

\section{Results}

\subsection{Extreme Value Analysis}

The results of the extreme values analysis for significant wave height are shown in Table $\mathbf{3}$ for the five buoys considered in this study for 1, 5, 10, 25, 50, and 100-year return periods. For each buoy, two estimates of the extreme significant wave height were made based on the historical and POT methods. The POT results are recommended for design. For the historical method, the data sampling that gave the best fit as determined from a least squares analysis is given. For the POT method, the time window, w, in days and the significant wave height threshold, th, in meters, that gave the best fit as described above are provided. The mean, $\mu$, and the number of 
standard deviations above the mean required to reach the selected threshold, $\mathrm{k}$, are also provided. The shape and scale parameters for the GP distribution are also provided for the POT method. The $90 \%$ confidence intervals for the POT method for the predicted extreme significant wave heights are also provided. The 50 -year significant wave height, a critical design parameter for offshore wind turbines per the American Bureau of Shipping (ABS) Guide for Building and Classing Floating Offshore Wind Turbines (2013) and IEC 61400-3 (2009), for the buoys considered ranged from approximately from $4.7 \mathrm{~m}$ to $9.8 \mathrm{~m}$ for near shore and far offshore buoys.

A comparison of the confidence intervals shown in Table 3 for the 50-year return period significant wave height is now presented. The 50-year return period event is of particular interest because it is specified by the offshore wind turbine design standards such ABS (2013) and IEC (2009). These intervals were estimated using a parameterized bootstrap method recommended for extreme value estimates by Kysely (2007) and Coles and Simiu (2003). The confidence intervals for the 50-year estimate of significant wave height for the longer buoy records from NOAA (27-31-year data record) are $+20 \% /-15 \%$ different from the estimated value for NOAA 44005 and $+28 \% /-22 \%$ different for NOAA 44007. The confidence intervals for 50-year estimate for significant wave height for the shorter record buoy records from UMaine (7-year data record) have larger confidence intervals. For buoy E01, the range is $+49 \% /-31 \%$. For Buoy F01 the range is $+30 /-23 \%$. For Buoy I01 the range is $+42 \% /-15 \%$. The confidence values are larger for the UMaine buoys as expected given the shorter seven year data records.

The predicted extreme 8-minute average wind speeds and 5-second average gust wind speeds are shown in Table 4 and Table 5. The extreme gust wind speeds were estimated using the results from the POT method multiplied by the annual mean gust factor for each buoy shown in Table 6. The threshold, th, mean, $\mu$, and number of standard deviations above the mean required to reach the threshold, $\mathrm{k}$, are provided in meters per second. The UMaine buoy wind speeds are at an elevation of $4 \mathrm{~m}$ and the NOAA wind speeds are at an elevation of $5 \mathrm{~m}$. The 50-year 8-minute average wind speeds ranges from $22.2 \mathrm{~m} / \mathrm{s}$ to $25.2 \mathrm{~m} / \mathrm{s}$ for all of the buoys. The 50 -year five second gust wind speed ranged from $28.5 \mathrm{~m} / \mathrm{s}$ to $30.7 \mathrm{~m} / \mathrm{s}$ for all of the buoys. Confidence intervals are also provided for the 8 -minute and gust wind speeds using the same parametric bootstrap procedure completed for the extreme significant wave height estimates. Similar to the wave heights, the estimates made with longer data records are noticeably smaller.

Estimates for extreme significant wave height and wind speed using standard thresholds equal to $\mu$ plus $1.4 \mathrm{k}$ and $\mu$, plus 2.0k are provided in the appendix in Table 8 and Table 9. The preferred time windows shown in Table 3 and 
Table 4 were used to generate the results in Table 8 and 9. These estimates compare well with those presented in the Tables 3 and 4.

\subsection{Mean Associated Period}

The mean associated wave peak periods for the extreme significant wave height estimates made with the POT method given in Table 2 are shown in Table 5. The parameters a, b, and c in Table 5 correspond to the following equation for the fitted power law equation given by:

$$
T_{p}=a \cdot H s^{b}+c
$$

where $T_{p}$ is the peak spectral period. The numbers in parentheses indicate the parameters that define the lower and upper bounds of the $95 \%$ confidence interval. A three parameter power law fit was selected based on a comparison of the $\mathrm{R}^{2}$ value from a three parameter fit and two parameter fit. A two parameter fit was also considered as it is often used for offshore design (e.g. DNV, 2010). For the buoy data sets considered here a three parameter power law fit gave better results as indicated by the $\mathrm{R}^{2}$ value of the two fits.

\subsection{Wind Design Parameters}

Relevant industry wind design parameters estimated from the buoy data and NREL published data are shown in Table 6. The annual average 8-minute wind speed and ISO corrected 10-minute wind speed on the buoy is presented for each buoy. 10-minute averages are presented in addition to the eight-minute wind speed data to accommodate standard wind engineering practice of using 10-minute average wind speed. The annual mean wind shear power law coefficient uncertainty is not available. This is because only an annual mean wind speed was provided from NREL from which the coefficient was derived.

\section{Discussion}

The following discussion includes commentary on the differences between the two methods used to estimate extreme values as well as a comparison of the preferred estimation method with past work. Extreme wind speeds and wind shear power exponents are compared with ASCE published design standards for coastal onshore regions in Maine.

\subsection{Comparison of Historical and POT Methods}


The extreme value estimates for significant wave height, 8-minute average wind speed, and 5-second average gust wind speed shown in Tables 2, 3, and 4 indicate that for all three parameters, the historical method consistently predicted larger values than the POT analysis. For significant wave height, the historical method predicted values up to $30 \%$ larger and on average $13 \%$ larger. For 8 -minute average wind speed, the historical method predicted values up to $27 \%$ larger and on average $11 \%$ larger. These differences are likely largely due to the inclusion of serially correlated data points in the historical method. This is the main drawback of the historical method. Analyses using the historical method have previously been shown to over predict extreme values even though the data showed a good fit in the probability plot (Buisand, 1984). Therefore, the POT predictions are expected to be more accurate. The POT method predictions are used for comparison with past extreme value estimates in the next section.

\subsection{Comparison of Extreme Significant Wave Height Predictions to Public Data}

There are several published studies presenting extreme significant wave height predictions. Neu $(1976,1982)$ produced several papers predicting extreme significant wave heights based on shipboard observations and wave probe measurements along the Atlantic coast for coarse $5^{0}$ x $5^{0}$ square regions. Godshall et al. (1980) published similar analyses based on shipboard observations for finer $1^{0} \times 1^{0}$ square regions. Walker (1984) has also published predictions of extreme significant wave heights from shipboard observations in $5^{0}$ x $5^{0}$ squares. Estimates for extreme significant wave heights have also been produced by Panchang et al. (1990, 1999, 2006 and 2008) using a regional wave hindcast model. Comparisons are made with an early model with a grid spacing 27.4 nautical miles.

Predictions of 100 year significant wave heights made using the POT method are compared with the work of Godshall et al. and Panchang et al. in Table 7. Walker and Neu were not compared due to the coarseness of their grids. For Buoy E01, the predictions from this study compared well with Panchang but differed significantly with Godshall. Godshall's prediction closest to Buoy E01 covers a large area including shallow water may have led to lower predictions for this point while Panchang's model data point closest to Buoy E01 resides in relatively open water free from the coast. For Buoy F01, significant differences exist between the POT method and Panchang and Godshall's results. This is attributable to Buoy F01's location within the mouth of Penobscot Bay which is on the very edge of both Panchang's and Godhsall's closest output points. Similar arguments can be made for Buoy I01. NOAA Buoy 44005 showed very good agreement between the POT method estimates and Panchang and 
Godshall's results. This buoy is located far offshore and both Panchang's and Godshall's output areas do not include coastline and the water depth is relatively constant. The POT method predictions from NOAA buoy 44007 agreed within $10 \%$ of Panchang's estimates but are 30\% different from Godshall's. These differences again are possibly due previous estimates' grid coarseness. In general, the predictions from this study compared favourably for open water locations. In regions closer to shore the predictions compare less favourably.

\subsection{Comparison of Estimated Wind Design Conditions to ASCE-7}

No extreme offshore wind speeds for the Gulf of Maine have been published. The American Society of Civil Engineers' publication, ASCE-7, (2010) estimates the 50-year return period 3-second gust for the entire Maine onshore coast at $10 \mathrm{~m}$ above sea level to be $45 \mathrm{~m} / \mathrm{s}$. Using the wind shear exponent estimated from the combined buoy and NREL data and correcting from 5-second to three second time average periods following ISO 19901-1, the estimated extreme wind speeds at the buoy locations were corrected for a $10 \mathrm{~m}$ elevation and 3-second averaging period. The results are shown in Table 8. The extreme gust wind speeds from this study were found to be -20 to- $26 \%$ less than ASCE. The wind shear exponents for each buoy are also compared with the recommended value of 0.15 from ASCE for coastal exposure conditions. The wind shear exponents provided from ASCE and determined in this study are relatively close to those recommended by IEC 61400-3, offshore wind turbine design standard which a value of 0.14 for normal offshore wind conditions. The wind shear exponents varied from 0.13 to 0.19 in this study with the 0.19 being an outlier. The values estimated in this study should be used carefully as they are based on utilizing two independent data sources.

\section{Summary and Conclusions}

This analysis presented in the paper presents key wave and wind design parameters required in the design of offshore wind turbines near several possible wind turbine locations. These design parameters were estimated based on buoy data records of seven to twenty-five years. We have calculated extreme wind speeds, extreme significant wave heights and mean associated peak periods for offshore Maine. This work is intended to provide a starting point for detailed engineering design specifications for future wind energy development throughout the Gulf of Maine with future data reducing estimate uncertainty. Site specific data will likely be required for a future project and values presented in this paper could be useful for initial planning, general understanding of the wave climate in the Gulf of Maine, and possible calibration of hindcast models for other sites. 
The historical and POT extreme value estimation methods were used to predict extreme significant wave height, eight minute wind average speed, and five second average gust wind speed at five buoy sites. The results from these two methods were compared and the historical method was found to consistently over predict the extreme events likely due to serially correlated data points, a known limitation of the historical method. The predictions made by POT method are therefore recommended for design over the historical method.

Extreme significant wave height predictions using the POT method compared well with past estimates based on hindcast model output and shipboard observations for the open water sites. Extreme significant wave heights estimated from buoys closer to shore differed considerably from past work likely due to coastline distortion not captured in previous studies. Therefore, these new predictions are more useful for projects nearer to the coastline where data is scarce.

Extreme wind speeds and wind shear coefficients predicted from the POT method in this study were adjusted for elevation and time averaging period to agree with ASCE published onshore coastal values to allow for comparison as no other published data offshore Maine exists. The extreme wind speeds compared were up to $27 \%$ lower than the ASCE values. The wind shear values compared well with the ASCE published values.

\section{Acknowledgements}

The authors would like to acknowledge the support of the US Department of Energy Office of Energy Efficiency and Renewable Energy Grant Number DE-EE0002981 and DE-EE0003278, the National Science Foundation (PFI) Grant Number IIP-0917974, the State of Maine 2010 State Bond, the Maine Technology Institute grant numbers CIP 111 and CIP 120, the Rockerfeller Brothers, the Davis Family Foundation, the University of Maine, the University of Maine School of Marine Sciences- Physical Oceanography Group for providing the data used in this study, the National Oceanographic and Atmospheric Administration: National Data Buoy Center for providing the data used in this study and Dr. Qingping Zou for reviewing this work. 


\section{References}

American Bureau of Shipping (ABS) (2013). Guide for Building and Classing Floating Offshore Wind Turbines. American Society of Civil Engineers. (2010). Minimum Design Loads for Buildings and Other Structures. ASCE/SEI 7-10. USA: American Society of Civil Engineers.

Buishand, T.A. (1984). The Effect of Seasonal Variation and Serial Correlation on the Extreme Value Distribution of Rainfall Data. Journal of Climate and Applied Meteorology. Volume 24. P 154-160.

Burton, T. S. (2001). Wind Energy Handbook. West Sussex, England: John Wiley \& Sons, Ltd.

Castillo, E.(1988). Extreme Value Theory in Engineering. Academic Press Inc.

Coles, S. (2001). An Introduction to Statistical Modeling of Extreme Values. London: Springer-Verlag.

Coles, S. and Simiu, E. (2003). Estimating Uncertainty in the Extreme Value Analysis of Data Generated by a Hurricane Simulation Model. Journal of Engineering Mechanics. ASCE, November, 2003. p.1288-1294.

Davison, A.C. \& Smith, R.L. (1990). Models for exceedances over high thresholds (with discussion). Journal of the Royal Statistical Society, B 52, No. 3. p.393-442.

Det Norske Veritsa (2010). Recommended Practice DNV-RP-C205, Environmental Conditions and Environmntal Loads.

Ferreira, J.A. \& Guedes Soares, C. (1998). An application of the peaks over threshold method to predict extremes of significant wave height. Journal of Offshore Mechanics and Arctic Engineering 120(3):165-176.

Gibson, R., Forristall, G. Z., Owrid, P., Grant, C., Smyth, R., Hagen, O., et al. (2009). Draft: Bias and Uncertainty in the Estimation of Extreme Wave Heights and Crests. 28th International Conference on Ocean, Offshore, and Arctic Engineering (pp. 1-11). Honolulu: ASME.

Godshall, F. A., Williams, R. G., Bishop, J. M., Everdale, F., \& Fehler, S. W. (1980). A Climatological and Oceanographic Analysis of the Georges Bank Region of the Outer Continental Shelf. Bureau of Land Management, US Department of the Interior. Washington, DC: US Department of Commerce, National Oceanic and Atmospheric Administration, Environmental Data and Information Service.

Gross, J. L., Heckert, N. A., Lechner, J. A., \& Simiu, E. (1995). Extreme Wind Estimates by the Conditional Mean Exceedance Procedure. NISTIR 5531. Gaithersburg, MD: US Department of Commerce, National Institute of Standards and Technology. 
Gumbel, E. J. (1958). Statistics of Extremes. New York: Columbia University Press.

International Eletrotechnical Commission (IEC) 61400-3:2009 (2009). Wind turbines - Part 3: Design requirements for offshore wind turbines.2009-02-11

International Organization for Standardization (ISO) 19901-1:2005 (2005). Petroleum and natural gas industries -Specific requirements for offshore structures -- Part 1: Metocean design and operating considerations.

Kysely, J. (2007). Notes and Correspondence A Cautionary Note on the Use of Nonparametric Bootstrap for Estimating Uncertainties of Extreme-Value Models. Journal of Applied Meteorology and Climatology. American Meteorological Society. Volume 47. December, 2008. P. 3236-3251.

MathWorks. (2011). Matlab. Natick, MA.

Mathiesen, M., Y. Goda, P.J. Hawkes, E. Mansard, M.J. Martin, E. Peltier, E.F. Thompson and G.Ph. van Vledder, (1994). Recommend practice for extreme wave analysis. Journal of Hydraulic Research, Vol. 32, No. 6.

Musial, W. D., \& Ram, B. (2010). Large Scale Offshore Windpower in the United States: Assessment of Opportunities and Barriers. NREL/TP-500-40745. National Renewable Energy Laboratory.

Naess, A. (1984). "Technical Note: On a rational approach to extreme value analysis. Applied Ocean Research, VolApplied Ocean Research, Vol. 6, No. 3 p.173-174.

National Oceanographic and Atmospheric Administration. (2011, January 26). Station 44005- Gulf of Maine - 78 NM East of Portsmouth, NH. Retrieved March 25, 2011, from National Data Buoy Center: http://www.ndbc.noaa.gov/station page.php?station=44005

National Oceanographic and Atmospheric Administration. (2011, January 26). Station 44007 (LLNR 75) PORTLAND 12 NM Southeast of Portland,ME. Retrieved March 25, 2011, from National Data Buoy Center: http://www.ndbc.noaa.gov/station_page.php?station=44007

Neu, H. J. (1976). Wave Climate of the North Atlantic - 1970. Dartmouth, Nova Scotia: Bedford Institute of Oceanography.

Neu, H. J. (1982). 11-Year Deep Water Wave Climate of Canadian Atlantic Waters. Dartmouth, Nova Scotia: Bedford Institute of Oceanography.

Panchang, V. G., Jeong, C., \& Li, D. (2008). Wave Climatology in Coastal Maine for Aquaculture and Other Applications. Estuaries and Coasts: J CERF, 31, 289-299. 
Panchang, V. G., Li, D., \& Jeong, C. (2006). Wave Climatology Influencing Aquaculture Operations in Coastal Maine. Texas A\&M University at Galveston, Department of Maritime Systems Engineering. National Oceanic \& Atmospheric Administration.

Panchang, V., Pearce, B. R., \& Puri, K. K. (1990). Hindcast Estimates of Extreme Wave Conditions in the Gulf of Maine. Technical Note. Applied Ocean Research, 12(1), 43-49.

Panchang, V., Zhao, L., \& Demirbilek, Z. (1999). Estimation of Extreme Wave Heights Using Geostat Measurements. Ocean Engineering, 26, 205-225.

Pettigrew, N., Wallinga, J., Neville, F., \& Schlenker, K. (2005). Gulf of Maine Ocean Observing System (GoMOOS): Current Measurement Approaches in a Prototype Integrated Ocean Observing System. Proceedings of the IEEE/OES Eigth Working COnference on Current MEasurement Technology (pp. 127131). IEE Xplore.

Ragan, P., Manuel, L. (2008). Statistical Extrapolation Metheods for Estimating Wind Turbine Extreme Loads. Journal of Solar Energy Engineering, Agust 2008, Vol. 130/ 031011.

Simiu, E.H., Ciccone, Z, DeMass. T. A.(2011). Design of Buildings for Wind : A Guide for ASCE 7-10 Standard Users and Designers of Special Structures (2nd Edition).Hoboken, NJ, USA: Wiley, 2011. p 141-149.

Sorenson, R. M. (1993). Basic Wave Mechanics for Coastal and Ocean Engineers. New York: John Wiley \& Sons, Inc.

Schwartz, M., Heimiller, D., Haymes, S., and Musial,M., (2010). Assessment of Offshore Wind Energy Resources for the United States. Technical Report NREL/TP-500-45889. June 2010. Golden, Colorado.

Toft, H.S., Naess, A., Saha, N., Sorensen, J.D. (2011). Response Load Extrapolation for Wind Turbines During Operation Based on Average Conditional Exceedance Rates. Wind Energy. 14: 749-766.

Tucker, M.J., and Pitt, E.G. (2001). Waves in Ocean Engineering. 164-166, 117-129.

Unversity of Maine (2009). University of Maine Ocean Oberserving System (UMOOS). Gulf of Maine Moored Buoy Program. Physical Oceanography Group School of Marine Sciences. Retrieved March 25, 2011, from http://gyre.umeoce.maine.edu/buoyhome.php. 
Walker, R. E. (1976). Wave Statistics for the North Atlantic - 1970. Data Series BI-D-76-3. Dartmouth, Nova Scotia: Bedford Institute of Oceanography.

Walker, R. E. (1984). Wave Statistics for the North Atlantic - 197010 1982. Canadian Data Report of Hydrography and Ocean Sciences 16. Dartmouth, Nova Scotia: Bedford Institute of Oceanography. 


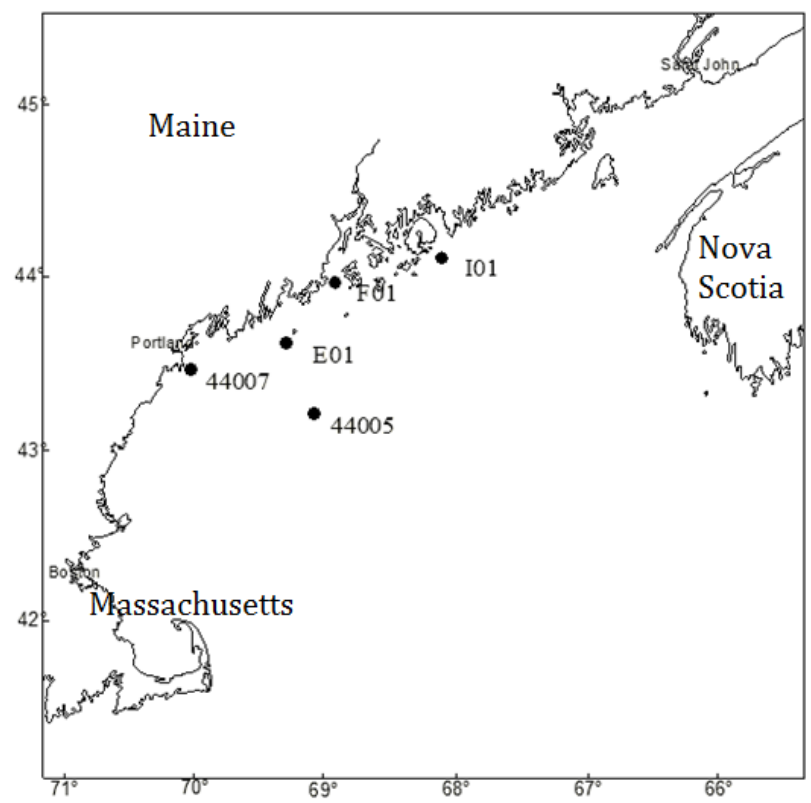

Figure 1: Gulf of Maine Buoys Considered in Study

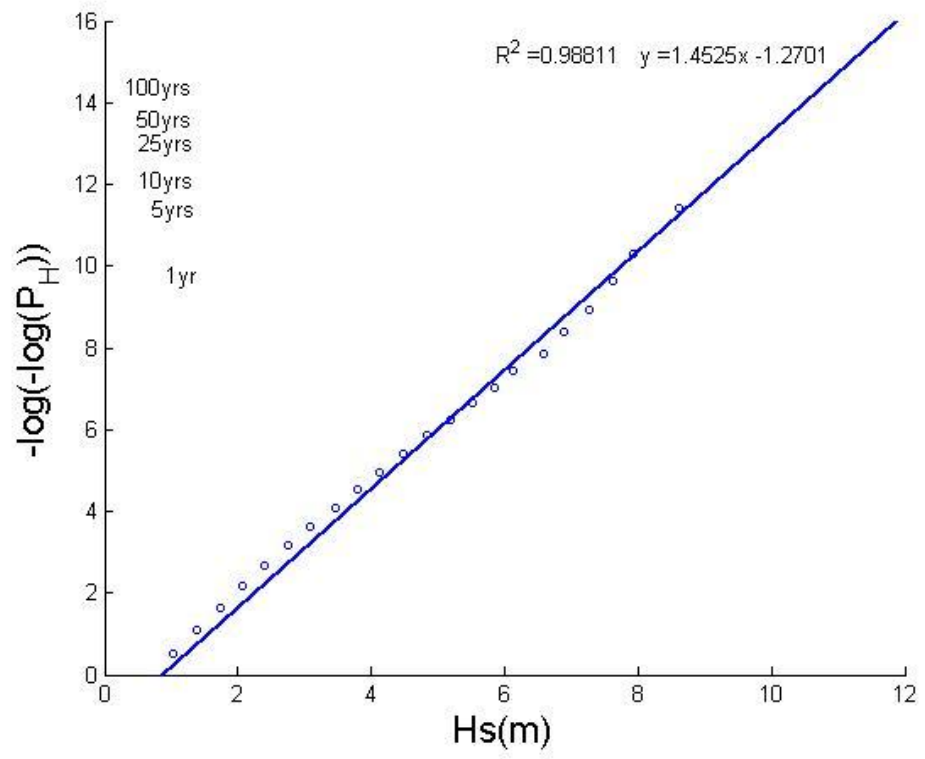

Figure 2: Reduced Variate vs. Extreme Significant Wave Height Plot for Buoy E01 


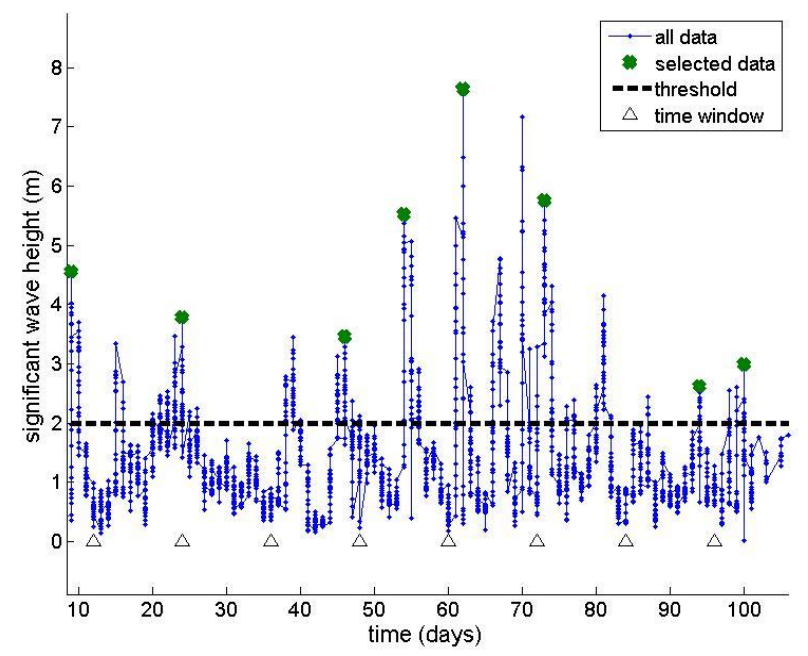

Figure 3: Buoy E01 POT Data Reduction Sample Plot 

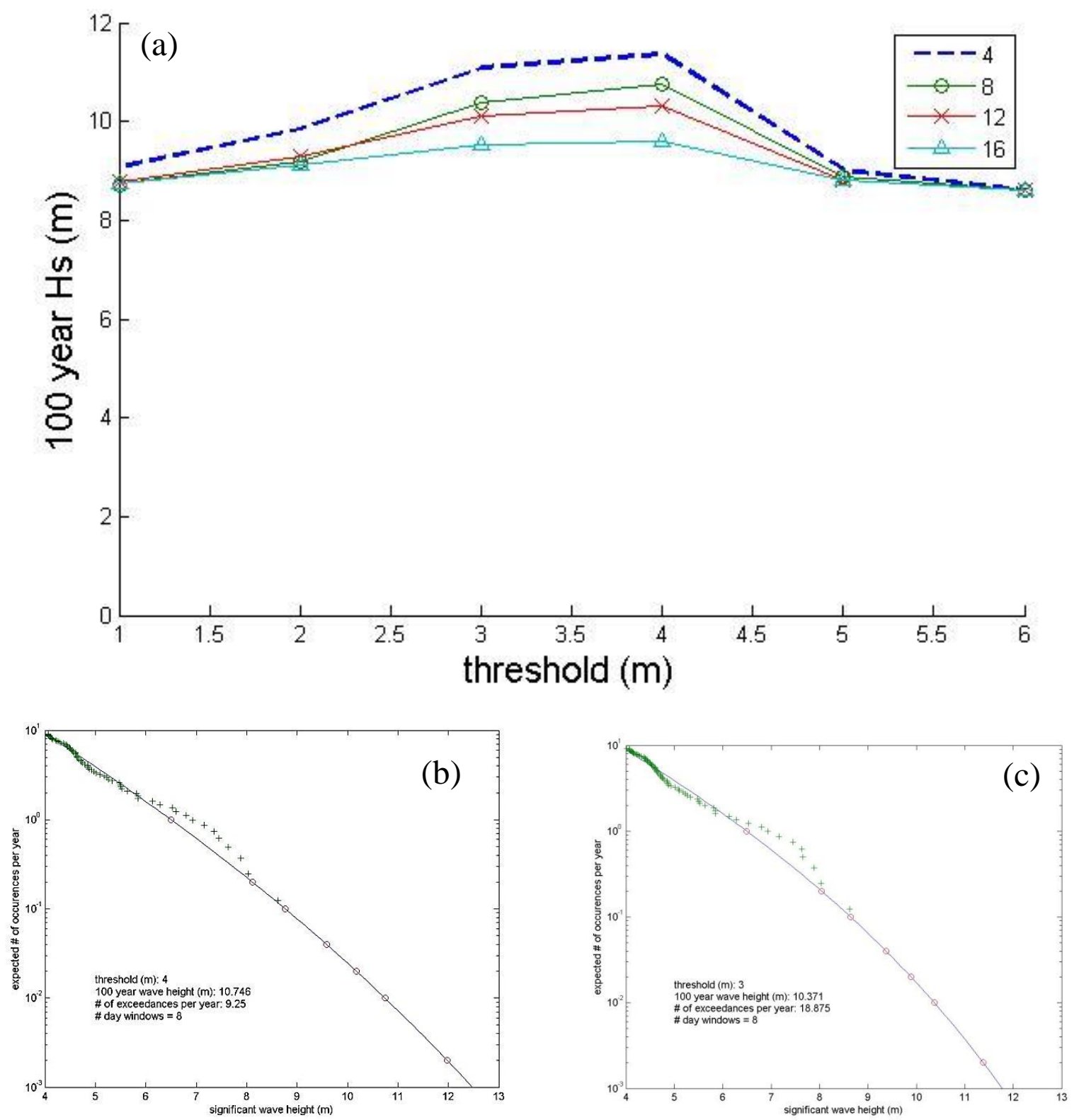

Figure 4: Sensitivity Study Results for Buoy E01 Significant Wave Height Data (a) Comparison of threshold and time window on 100 year significant wave height (b) Selected GPD Fit of data (c) Sample Fit That Was Not Selected 


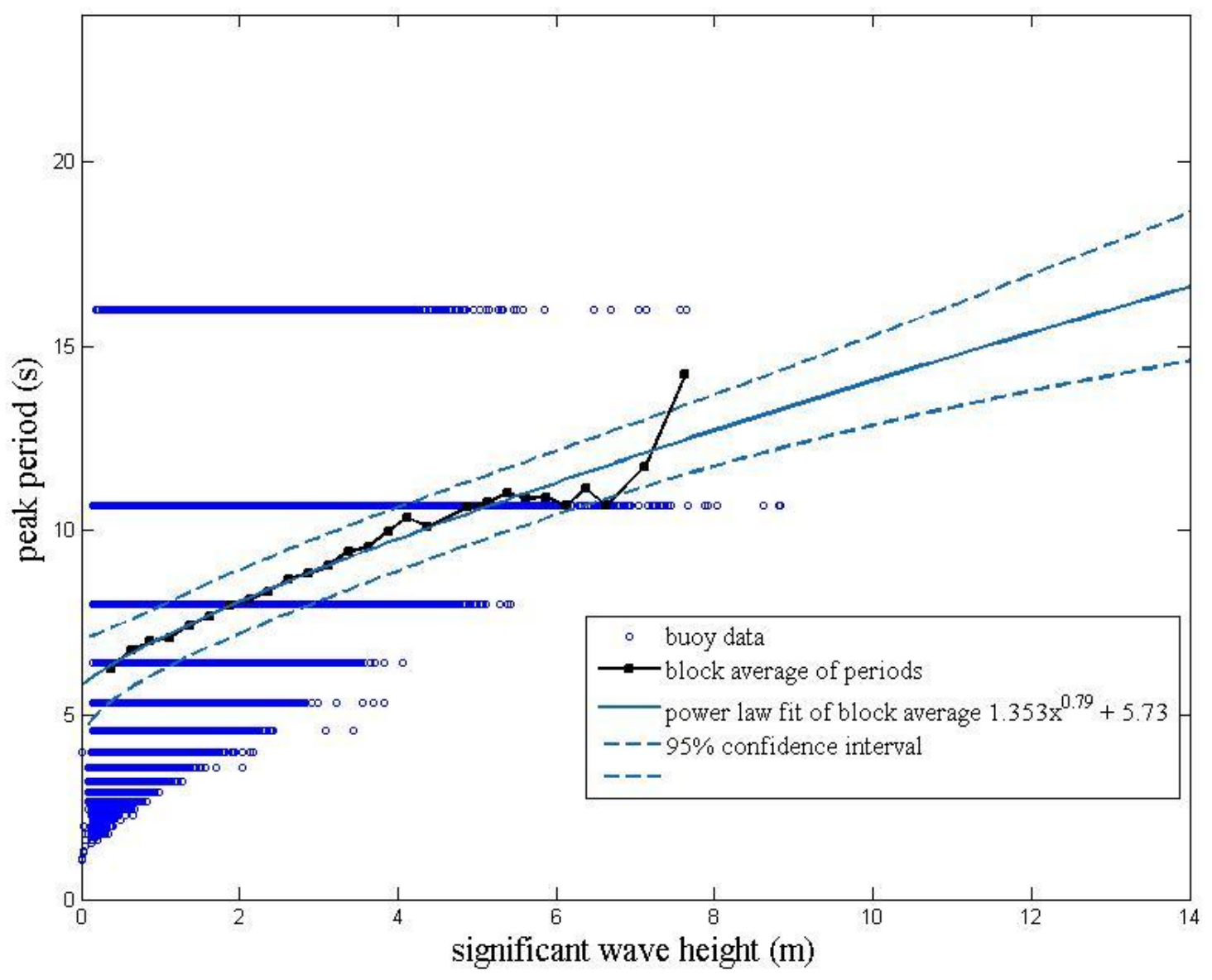

Figure 5: Sample Scatter Diagram of Peak Period and Significant Wave Height 
Table 1. Buoy characteristics

\begin{tabular}{|c|c|c|c|c|c|c|}
\hline Buoy & Latitude & Longitude & Location & $\begin{array}{c}\text { Depth } \\
\text { (m) }\end{array}$ & Data Time Range & $\begin{array}{c}\text { Length } \\
\text { (yrs) }\end{array}$ \\
\hline UMaine E01 & $43^{\circ} 42.86^{\prime} \mathrm{N}$ & $69^{\circ} 21.35^{\prime} \mathrm{W}$ & Monhegan Island, ME & 100 & Jan. 8, 2002 - Sept. $9^{\text {th }}, 2009$ & 7.8 \\
\hline UMaine F01 & $44^{\circ} 3.25^{\prime} \mathrm{N}$ & $68^{\circ} 59.87^{\prime} \mathrm{W}$ & Penobscot Bay, ME & 110 & Jan. 8, $2002-$ Sep. $17^{\text {th }}, 2009$ & 7.8 \\
\hline UMaine I01 & $44^{\circ} 6.35 \mathrm{~N}$ & $68^{\circ} 6.52^{\prime} \mathrm{W}$ & Acadia National Park, ME & 100 & Jan. $6^{\text {th }}, 2002-$ Sep. $16^{\text {th }}, 2009$ & 7.8 \\
\hline NOAA 44005 & $43^{\circ} 11.37^{\prime} \mathrm{N}$ & $69^{\circ} 8.38^{\prime} \mathrm{W}$ & East of Portsmouth, NH & 201 & Dec. $16^{\text {th }}, 1978-$ Dec. $31^{\text {st }}, 2009$ & 32 \\
\hline NOAA 44007 & $43^{\circ} 31.88^{\prime} \mathrm{N}$ & $70^{\circ} 8.65^{\prime} \mathrm{W}$ & Southeast of Portland, ME & 24 & Feb. 16, 1982 - Dec. $31^{\text {st }}, 2009$ & 29 \\
\hline
\end{tabular}

Table 2. Buoy data statistics

\begin{tabular}{|l|c|c|c|c|c|c|c|c|}
\hline \multirow{2}{*}{ Buoy } & \multicolumn{4}{|c|}{ significant wave height } & \multicolumn{4}{c|}{ 8-minute wind speed at 4m } \\
\cline { 2 - 9 } & $\begin{array}{c}\text { mean } \\
(\mathbf{m})\end{array}$ & $\begin{array}{c}\text { standard } \\
\text { deviation } \\
(\mathbf{m})\end{array}$ & skewness & kurtosis & $\begin{array}{c}\text { mean } \\
(\mathbf{m} / \mathbf{s})\end{array}$ & $\begin{array}{c}\text { standard } \\
\text { deviation } \\
(\mathbf{m} / \mathbf{s})\end{array}$ & skewness & kurtosis \\
\hline UMaine E01 & 1.2 & 0.8 & 1.9 & 9.0 & 5.6 & 3.2 & 0.6 & 2.8 \\
\hline UMaine F01 & 0.6 & 0.4 & 2.1 & 10.0 & 4.7 & 3.1 & 0.9 & 3.8 \\
\hline UMaine I01 & 1.3 & 0.8 & 1.9 & 8.2 & 5.9 & 3.5 & 0.6 & 2.8 \\
\hline NOAA 44005 & 1.6 & 1.0 & 1.7 & 7.1 & 6.6 & 3.6 & 0.6 & 3.1 \\
\hline NOAA 44007 & 0.9 & 0.6 & 2.5 & 13.0 & 5.6 & 3.2 & 0.6 & 3.2 \\
\hline
\end{tabular}


Table 3. Extreme significant wave height in meters

( $90 \%$ confidence intervals provided for POT method)

\begin{tabular}{|c|c|c|c|c|c|c|c|c|c|c|}
\hline \multirow[b]{2}{*}{$\begin{array}{c}\text { Return } \\
\text { Period } \\
\text { (yrs) }\end{array}$} & \multicolumn{2}{|c|}{ UMaine E01 } & \multicolumn{2}{|c|}{ UMaine F01 } & \multicolumn{2}{|c|}{ UMaine I01 } & \multicolumn{2}{|c|}{ NOAA 44005} & \multicolumn{2}{|c|}{ NOAA 44007} \\
\hline & $\begin{array}{l}\text { Historical } \\
\text { All data }\end{array}$ & $\begin{array}{l}\text { POT } \\
\mathrm{w}=4 \\
\text { th }=3 \\
\mu=1.2 \\
\mathrm{k}=4.0 \\
\text { shape }=-0.0513 \\
\text { scale }=1.1389\end{array}$ & $\begin{array}{l}\text { Historical } \\
\text { Daily max }\end{array}$ & $\begin{array}{l}\text { POT } \\
\mathrm{w}=4 \\
\text { th }=1 \\
\mu=0.6 \\
\mathrm{k}=2.6 \\
\text { shape }=-0.1391 \\
\text { scale }=0.7784\end{array}$ & $\begin{array}{l}\text { Historical } \\
\text { Daily max }\end{array}$ & $\begin{array}{l}\text { POT } \\
\mathrm{w}=4 \\
\text { th }=4 \\
\mu=1.3 \\
\mathrm{k}=4.8 \\
\text { shape }=-0.1830 \\
\text { scale }=1.2897\end{array}$ & $\begin{array}{l}\text { Historical } \\
\text { All data }\end{array}$ & $\begin{array}{l}\text { POT } \\
\mathrm{w}=8 \\
\text { th }=4 \\
\mu=1.6 \\
\mathrm{k}=4.0 \\
\text { shape }=-0.1667 \\
\text { scale }=1.4317\end{array}$ & $\begin{array}{l}\text { Historical } \\
\text { All data }\end{array}$ & $\begin{array}{l}\text { POT } \\
\mathrm{w}=8 \\
\text { th }=3 \\
\mu=0.9 \\
\mathrm{k}=4.7 \\
\text { shape }=-0.1605 \\
\text { scale }=1.4818\end{array}$ \\
\hline 1 & 7.6 & $6.4(5.3,7.7)$ & 3.5 & $3.4(2.9,3.9)$ & 7.1 & $6.7(5.8,8.0)$ & 9.1 & $7.0(6.4,7.6)$ & 7.0 & $5.8(5.2,6.6)$ \\
\hline 5 & 8.7 & $7.9(6.1,10.4)$ & 4.2 & $4.0(3.3,4.9)$ & 8.6 & $7.8(6.3,10.0)$ & 10.4 & $8.3(7.3,9.5)$ & 8.1 & $7.3(6.1,8.7)$ \\
\hline 10 & 9.2 & $8.5(6.3,11.6)$ & 4.5 & $4.3(3.4,5.3)$ & 9.3 & $8.2(6.4,10.8)$ & 10.9 & $8.8(7.6,10.2)$ & 8.5 & $7.8(6.4,9.5)$ \\
\hline 25 & 9.8 & $9.2(6.6,13.3)$ & 4.9 & $4.6(3.6,5.8)$ & 10.2 & $8.7(6.6,11.9)$ & 11.7 & $9.3(8.1,11.0$ & 9.1 & $8.4(6.7,10.6)$ \\
\hline 50 & 10.3 & $9.8(6.8,14.6)$ & 5.2 & $4.7(3.6,6.1)$ & 10.8 & $8.9(6.6,12.6)$ & 12.2 & $9.7(8.2,11.6)$ & 9.6 & $8.8(6.9,11.3)$ \\
\hline 100 & 10.7 & $10.3(7.0,16.0)$ & 5.5 & $4.9(3.7,6.4)$ & 11.5 & $9.2(6.7,13.3)$ & 12.8 & $10.0(8.5,12.2)$ & 10.1 & $9.2(7.3,12.0)$ \\
\hline
\end{tabular}

Notes:

1. POT predicted values are recommended for design purposes. Historical method is provided for comparative purposes only.

2. $90 \%$ confidence intervals provided in parentheses for POT method predictions only

Table 4. Extreme 8-minute average wind speeds in $\mathrm{m} / \mathrm{s}$ at $4-5 \mathrm{~m}$ above sea level

\begin{tabular}{|c|c|c|c|c|c|c|c|c|c|c|}
\hline \multirow[b]{2}{*}{$\begin{array}{c}\text { Return } \\
\text { Period } \\
(\text { yrs })\end{array}$} & \multicolumn{2}{|c|}{ UMaine E01 } & \multicolumn{2}{|c|}{ UMaine F01 } & \multicolumn{2}{|c|}{ UMaine I01 } & \multicolumn{2}{|c|}{ NOAA 44005} & \multicolumn{2}{|c|}{ NOAA 44007} \\
\hline & $\begin{array}{l}\text { Historical } \\
\text { All data }\end{array}$ & $\begin{array}{l}\text { POT } \\
\mathrm{w}=4 \\
\text { th }=14 \\
\mu=5.6 \\
\mathrm{k}=4.4 \\
\text { shape }=-0.0309 \\
\text { scale }=1.6797\end{array}$ & $\begin{array}{l}\text { Historical } \\
\text { Daily max }\end{array}$ & $\begin{array}{l}\text { POT } \\
\mathrm{w}=4 \\
\text { th }=13 \\
\mu=4.7 \\
\mathrm{k}=4.2 \\
\text { shape }=-0.1859 \\
\text { scale }=2.4854\end{array}$ & $\begin{array}{l}\text { Historical } \\
\text { Daily max }\end{array}$ & $\begin{array}{l}\text { POT } \\
\mathrm{w}=8 \\
\text { th }=14 \\
\mu=5.9 \\
\mathrm{k}=4.0 \\
\text { shape }=-0.1692 \\
\text { scale }=2.3806\end{array}$ & $\begin{array}{l}\text { Historical } \\
\text { All data }\end{array}$ & $\begin{array}{l}\text { POT } \\
\mathrm{w}=8 \\
\text { th }=15 \\
\mu=6.6 \\
\mathrm{k}=4.1 \\
\text { shape }=-0.2208 \\
\text { scale }=2.9581\end{array}$ & $\begin{array}{l}\text { Historical } \\
\text { All data }\end{array}$ & $\begin{array}{l}\text { POT } \\
\mathrm{w}=12 \\
\text { th }=14 \\
\mu=5.6 \\
\mathrm{k}=4.4 \\
\text { shape }=-0.2117 \\
\text { scale }=2.6368\end{array}$ \\
\hline 1 & 21.4 & $18.4(16.9,20.5)$ & 19.8 & $17.8(16.4,19.7)$ & 21.3 & $18.6(17.1,20.5)$ & 21.0 & $20.8(19.7,21.9)$ & 21.8 & $18.9(17.9,20.2)$ \\
\hline 5 & 24.2 & $20.8(18.0,25.2)$ & 23.6 & $20.0(17.5,23.5)$ & 25.4 & $20.9(18.2,24.5)$ & 24.9 & $23.0(21.325 .0)$ & 24.6 & $21.1(19.3,23.3)$ \\
\hline 10 & 25.4 & $21.8(18.3,27.4)$ & 25.3 & $20.8(17.8,24.9)$ & 27.1 & $21.7(18.5,26.1)$ & 26.6 & $23.8(21.826 .1)$ & 25.8 & $21.8(19.7,24.4)$ \\
\hline 25 & 27.0 & $23.1(18.7,30.6)$ & 27.4 & $21.7(18.1,26.8)$ & 29.4 & $22.6(18.8,28.2)$ & 28.9 & $24.6(22.227 .4)$ & 27.4 & $22.7(20.2,25.7)$ \\
\hline 50 & 28.2 & $24.1(19.0,33.2)$ & 29.1 & $22.2(18.3,29.3)$ & 31.1 & $23.2(19.0,29.6)$ & 30.6 & $25.2(22.528 .3)$ & 28.6 & $23.2(20.4,26.7)$ \\
\hline 100 & 29.4 & $25.0(19.2,36.0)$ & 30.7 & $22.7(18.4,31.8)$ & 32.8 & $23.7(19.1,31.1)$ & 32.3 & $25.6(22.829 .1)$ & 29.8 & $23.6(20.6,27.5)$ \\
\hline
\end{tabular}

Notes:

1. POT predicted values are recommended for design purposes. Historical method is provided for comparative purposes only.

2. $90 \%$ confidence intervals provided in parentheses for POT method predictions only

3. UMaine buoys wind speeds measured at $4 \mathrm{~m}$ above sea level. NOAA buoys wind speeds measured at $5 \mathrm{~m}$ above sea level. 
Table 5 Extreme 5 -second gust wind speeds in $\mathrm{m} / \mathrm{s}$

\begin{tabular}{|c|l|l|l|l|l|}
\hline $\begin{array}{l}\text { Return } \\
\text { Period } \\
(\text { yrs })\end{array}$ & UMaine E01 & UMaine F01 & UMaine I01 & NOAA 44005 & NOAA 44007 \\
\hline 1 & $22.6(20.8,25.2)$ & $23.5(21.6,26.0)$ & $23.1(21.2,25.4)$ & $25.4(24.0,26.7)$ & $23.2(22.0,24.8)$ \\
\hline 5 & $25.6(22.1,31)$ & $26.4(23.1,31.0)$ & $25.9(22.6,30.4)$ & $28.1(26.0,30.5)$ & $26.0(23.7,28.7)$ \\
\hline 10 & $26.8(22.5,33.7)$ & $27.5(23.5,32.9)$ & $26.9(22.9,32.4)$ & $29.0(26.6,31.8)$ & $26.8(24.2,30.0)$ \\
\hline 25 & $28.4(23.0,37.6)$ & $28.6(23.9,35.4)$ & $28.0(23.3,35.0)$ & $30.0(27.1,33.4)$ & $27.9(24.8,31.6)$ \\
\hline 50 & $29.6(23.4,40.8)$ & $29.3(24.2,38.7)$ & $28.8(23.6,36.7)$ & $30.7(27.5,34.5)$ & $28.5(25.1,32.8)$ \\
\hline 100 & $30.8(23.6,44.3)$ & $30.0(24.3,42.0)$ & $29.4(23.7,38.6)$ & $31.2(27.8,35.5)$ & $29.0(25.3,33.8)$ \\
\hline
\end{tabular}

Notes:

1. Extreme gusts where calculated using POT predicted values from Table 3 multiplied by annual mean gust factor

2. UMaine buoys wind speeds measured at $4 \mathrm{~m}$ above sea level. NOAA buoys wind speeds measured at $5 \mathrm{~m}$ above sea level.

3. $90 \%$ confidence intervals provided in parentheses

Table 6. Annual mean wind data and wind design parameters

\begin{tabular}{|l|l|l|l|l|l|}
\hline Buoy & $\begin{array}{c}\text { UMaine } \\
\text { E01 }\end{array}$ & $\begin{array}{l}\text { UMaine } \\
\text { F01 }\end{array}$ & $\begin{array}{c}\text { UMaine } \\
\text { I01 }\end{array}$ & $\begin{array}{c}\text { NOAA } \\
\text { 44005 }\end{array}$ & $\begin{array}{c}\text { NOAA } \\
\text { 44007 }\end{array}$ \\
\hline Mean 8-minute wind speed at sensor height (m/s) & 5.6 & 4.7 & 5.9 & 6.7 & 5.6 \\
\hline Mean 5-second gust wind speed at sensor height (m/s) & 6.9 & 6.2 & 7.3 & 8.2 & 6.9 \\
\hline Mean gust factor & 1.23 & 1.32 & 1.24 & 1.22 & 1.23 \\
\hline Wind shear power law exponent & 0.16 & 0.19 & 0.14 & 0.13 & 0.13 \\
\hline Mean 10-minute wind speed at 90 m (m/s) & 9.1 & 8.5 & 9.0 & 9.6 & 8.0 \\
\hline Mean 5-second gust wind speed at 90 m (m/s) & 11.0 & 11.2 & 11.1 & 12.3 & 10.0 \\
\hline NREL predicted mean 10-minute wind speed (m/s) at 90 m (2010) & $9.0-9.5$ & $8.0-8.5$ & $9.0-9.5$ & $9.5-10.0$ & $8.0-8.5$ \\
\hline
\end{tabular}


Table 7. Mean peak wave periods for predicted extreme significant wave heights in seconds (95\% confidence intervals provided for estimated power law parameters)

\begin{tabular}{|c|c|c|c|c|c|}
\hline $\begin{array}{l}\text { Return } \\
\text { Period } \\
\text { (yrs) }\end{array}$ & UMaine E01 & UMaine F01 & UMaine I01 & NOAA 44005 & NOAA 44007 \\
\hline 1 & 11.7 & 9.7 & 11.2 & 12.3 & 13.0 \\
\hline 5 & 12.8 & 10.4 & 11.7 & 14.1 & 15.4 \\
\hline 10 & 13.3 & 10.7 & 11.9 & 14.1 & 16.2 \\
\hline 25 & 13.8 & 11.1 & 12.1 & 15.6 & 17.2 \\
\hline 50 & 14.2 & 11.2 & 12.2 & 16.2 & 18.0 \\
\hline 100 & 14.6 & 11.4 & 12.3 & 16.7 & 18.7 \\
\hline $\mathrm{a}$ & $1.353 \quad(0.2348,2.47)$ & $1.224 \quad(0.5207,1.928)$ & $2.238 \quad(0.6027,3.874)$ & $0.2173(0.2016,0.233)$ & $0.3989(0.37,0.4279)$ \\
\hline $\mathrm{b}$ & $0.7900(0.4514,1.129)$ & $0.9785(0.6473,1.31)$ & $0.5413(0.2929,0.7897)$ & $1.656(1.613,1.7)$ & $1.506 \quad(1.453,1.559)$ \\
\hline $\mathrm{c}$ & $5.730 \quad(4.409,7.052)$ & $5.635 \quad(4.911,6.36)$ & $4.904 \quad(3.173,6.635)$ & $6.854 \quad(6.831,6.877)$ & $7.406 \quad(7.38,7.432)$ \\
\hline
\end{tabular}


Table 8. 100 year return period significant wave heights predicted in this study as compared to other published values nearby each buoy.

\begin{tabular}{|l|c|c|c|c|c|}
\hline Analysis Method & E01 & F01 & I01 & $\mathbf{4 4 0 0 5}$ & $\mathbf{4 4 0 0 7}$ \\
\hline POT method & 10.3 & 4.9 & 9.2 & 10.0 & 9.2 \\
\hline Panchang et al. (1990) & 10.6 & 11.1 & 11.7 & 10.8 & 10.1 \\
\hline Godshall et al. (1980) & 7.11 & 12.89 & NA & 10.33 & 6.94 \\
\hline \% Difference with Panchang & $-3 \%$ & $-56 \%$ & $-21 \%$ & $-7 \%$ & $-9 \%$ \\
\hline \% Difference with Godshall & $45 \%$ & $-62 \%$ & NA & $-3 \%$ & $33 \%$ \\
\hline
\end{tabular}

Table 9. Comparison of wind shear exponents and 50yr 3-second gust wind speeds estimates to ASCE-7

\begin{tabular}{|c|c|c|c|c|c|}
\hline Buoy & $\begin{array}{c}\text { UMaine } \\
\text { E01 }\end{array}$ & $\begin{array}{c}\text { UMaine } \\
\text { F01 }\end{array}$ & $\begin{array}{c}\text { UMaine } \\
\text { I01 }\end{array}$ & $\begin{array}{c}\text { NOAA } \\
44005\end{array}$ & $\begin{array}{c}\text { NOAA } \\
44007 \\
\end{array}$ \\
\hline 50 year 5 -scond gust wind speed at sensor height $(\mathrm{m} / \mathrm{s})$ & 29.6 & 29.3 & 28.8 & 30.7 & 28.5 \\
\hline Wind shear power law exponent from data & 0.16 & 0.19 & 0.14 & 0.13 & 0.13 \\
\hline Wind shear power law exponent per ASCE-7coastal exposure conditions & \multicolumn{5}{|c|}{0.15} \\
\hline Wind shear power law exponent $\%$ difference from ASCE-7 & $7 \%$ & $27 \%$ & $-7 \%$ & $-13 \%$ & $-13 \%$ \\
\hline ISO conversion from 5-second to 3 -second wind speed & \multicolumn{5}{|c|}{1.034} \\
\hline 50 year 3 -second gust wind speed at $10 \mathrm{~m}(\mathrm{~m} / \mathrm{s})$ & 35.4 & 36.1 & 33.9 & 35.8 & 33.2 \\
\hline Maine coastal ASCE 50 year 3-second gust wind speed at $10 \mathrm{~m}(\mathrm{~m} / \mathrm{s})$ & \multicolumn{5}{|c|}{45.0} \\
\hline 50 year 3-second gust $\%$ difference from ASCE-7 & $-21 \%$ & $-20 \%$ & $-25 \%$ & $-21 \%$ & $-26 \%$ \\
\hline
\end{tabular}


Table 10. Extreme significant wave height in meters for thresholds $(\mu+1.4 \sigma)$ and $(\mu+2.0 \sigma)$ ( $90 \%$ confidence intervals provided for POT method)

\begin{tabular}{|c|c|c|c|c|c|c|c|c|c|c|}
\hline \multirow[b]{2}{*}{$\begin{array}{c}\text { Return } \\
\text { Period } \\
\text { (yrs) }\end{array}$} & \multicolumn{2}{|c|}{ UMaine E01 } & \multicolumn{2}{|c|}{ UMaine F01 } & \multicolumn{2}{|c|}{ UMaine I01 } & \multicolumn{2}{|c|}{ NOAA 44005} & \multicolumn{2}{|c|}{ NOAA 44007} \\
\hline & $\begin{array}{l}\text { POT } \\
w=4 \\
k=1.4 \\
\text { shape }=-0.1058 \\
\text { scale }=1.338\end{array}$ & $\begin{array}{l}\text { POT } \\
w=4 \\
k=2.0 \\
\text { shape }=-0.0769 \\
\text { scale }=1.221\end{array}$ & $\begin{array}{l}\text { POT } \\
w=4 \\
k=1.4 \\
\text { shape }=-0.1619 \\
\text { scale }=0.7841\end{array}$ & $\begin{array}{l}\text { POT } \\
w=4 \\
k=2.0 \\
\text { shape }=-0.1543 \\
\text { scale }=0.7330\end{array}$ & $\begin{array}{l}\text { POT } \\
w=4 \\
k=1.4 \\
\text { shape }=-0.2485 \\
\text { scale }=1.8051\end{array}$ & $\begin{array}{l}\text { POT } \\
w=4 \\
k=2.0 \\
\text { shape }=-0.2400 \\
\text { scale }=1.657\end{array}$ & $\begin{array}{l}\text { POT } \\
w=8 \\
k=1.4 \\
\text { shape }=-0.1752 \\
\text { scale }=1.5262\end{array}$ & $\begin{array}{l}\text { POT } \\
w=8 \\
k=2.0 \\
\text { shape }=-0.1184 \\
\text { scale }=1.3163\end{array}$ & $\begin{array}{l}\text { POT } \\
w=8 \\
k=1.4 \\
\text { shape }=-0.0924 \\
\text { scale }=1.3538\end{array}$ & $\begin{array}{l}\text { POT } \\
\mathrm{w}=8 \\
\mathrm{k}=2.0 \\
\text { shape }=-0.0602 \\
\text { scale }=1.2713\end{array}$ \\
\hline 1 & $6.4(5.4,7.6)$ & $6.4(5.4,7.7)$ & $3.4(2.9,4.0)$ & $3.4(2.9,4.0)$ & $6.8(5.8,7.9)$ & $6.8(5.8,7.9)$ & $7.0(6.4,7.7)$ & $7.0(6.4,7.6)$ & $5.5(4.9,6.2)$ & $5.6(4.9,6.3)$ \\
\hline 5 & $7.7(6.1,9.7)$ & $7.8(6.1,10.0)$ & $4.0(3.2,4.9)$ & $4.0(3.2,5.0)$ & $7.7(6.4,9.4)$ & $7.7(6.3,9.5)$ & $8.2(7.3,9.3)$ & $8.3(7.4,9.4)$ & $7.0(6.0,8.3)$ & $7.2(6.0,8.6)$ \\
\hline 10 & $8.2(6.4,10.6)$ & $8.4(6.4,11.1)$ & $4.2(3.3,5.3)$ & $4.2(3.3,5.4)$ & $8.0(6.5,9.9)$ & $8.1(6.5,10.0)$ & $8.6(7.6,9.8)$ & $8.8(7.7,9.4)$ & $7.6(6.3,9.1)$ & $7.9(6.4,9.6)$ \\
\hline 25 & $8.8(6.7,11.7)$ & $9.0(6.7,12.4)$ & $4.5(3.5,5.7)$ & $4.5(3.4,5.8)$ & $8.4(6.7,10.4)$ & $8.4(6.6,10.6)$ & $9.1(7.9,10.4)$ & $9.4(8.1,11.0)$ & $8.3(6.8,10.2)$ & $8.7(6.9,10.9)$ \\
\hline 50 & $9.3(6.9,12.5)$ & $9.5(6.9,13.5)$ & $4.6(3.5,6.0)$ & $4.6(3.5,6.2)$ & $8.6(6.8,10.8)$ & $8.6(6.7,11.1)$ & $9.4(8.0,10.8)$ & $9.8(8.4,11.6)$ & $8.8(7.1,11.0)$ & $9.3(7.2,11.9)$ \\
\hline 100 & $9.6(7.0,13.3)$ & $10.0(7.0,14.5)$ & $4.8(3.6,6.3)$ & $4.8(3.6,6.5)$ & $8.7(6.8,11.1)$ & $8.8(6.8,11.4)$ & $9.6(8.2,11.2)$ & $10.2(8.6,12.2)$ & $9.3(7.3,11.7)$ & $9.9(7.5,13.0)$ \\
\hline
\end{tabular}

Table 11. Extreme 8-minute wind speed in meters/s for thresholds $(\mu+1.4 \sigma)$ and $(\mu+2.0 \sigma)$

( $90 \%$ confidence intervals provided for POT method)

\begin{tabular}{|c|c|c|c|c|c|c|c|c|c|c|}
\hline \multirow[b]{2}{*}{$\begin{array}{c}\text { Return } \\
\text { Period } \\
\text { (yrs) }\end{array}$} & \multicolumn{2}{|c|}{ UMaine E01 } & \multicolumn{2}{|c|}{ UMaine F01 } & \multicolumn{2}{|c|}{ UMaine I01 } & \multicolumn{2}{|c|}{ NOAA 44005} & \multicolumn{2}{|c|}{ NOAA 44007} \\
\hline & $\begin{array}{l}\text { POT } \\
\mathrm{w}=4 \\
\mathrm{k}=1.4 \\
\text { shape }=-0.4318 \\
\text { scale }=4.1377\end{array}$ & $\begin{array}{l}\text { POT } \\
\mathrm{w}=4 \\
\mathrm{k}=2.0 \\
\text { shape }=-0.1164 \\
\text { scale }=2.4394\end{array}$ & $\begin{array}{l}\text { POT } \\
\mathrm{w}=4 \\
\mathrm{k}=1.4 \\
\text { shape }=-0.3127 \\
\text { scale }=4.4331\end{array}$ & $\begin{array}{l}\text { POT } \\
\mathrm{w}=4 \\
\mathrm{k}=2.0 \\
\text { shape }=-0.1746 \\
\text { scale }=2.7652\end{array}$ & $\begin{array}{l}\text { POT } \\
\mathrm{w}=8 \\
\mathrm{k}=1.4 \\
\text { shape }=-0.3368 \\
\text { scale }=4.5908\end{array}$ & $\begin{array}{l}\text { POT } \\
\mathrm{w}=8 \\
\mathrm{k}=2.0 \\
\text { shape }=-0.2322 \\
\text { scale }=3.0087\end{array}$ & $\begin{array}{l}\text { POT } \\
\mathrm{w}=8 \\
\mathrm{k}=1.4 \\
\text { shape }=-0.3228 \\
\text { scale }=4.8548\end{array}$ & $\begin{array}{l}\text { POT } \\
\mathrm{w}=8 \\
\mathrm{k}=2.0 \\
\text { shape }=-0.2426 \\
\text { scale }=3.3821\end{array}$ & $\begin{array}{l}\text { POT } \\
\mathrm{w}=12 \\
\mathrm{k}=1.4 \\
\text { shape }=-0.3017 \\
\text { scale }=4.366\end{array}$ & $\begin{array}{l}\text { POT } \\
\mathrm{w}=12 \\
\mathrm{k}=2.0 \\
\text { shape }=-0.2318 \\
\text { scale }=3.1511\end{array}$ \\
\hline 1 & $17.9(16.6,19.3)$ & $19.0(17.3,21.1)$ & $18.0(16.1,20.1)$ & $17.7(16.2,19.5)$ & $19.4(17.4,21.6)$ & $18.8(17.2,20.8)$ & $21.3(20.1,22.6)$ & $20.8(19.7,22.0)$ & $19.4(18.2,20.6)$ & $18.9(17.8,20.1)$ \\
\hline 5 & $18.8(17.2,20.5)$ & $21.4(18.6,24.9)$ & $20.1(17.4,23.1)$ & $20.0(17.6,22.9)$ & $21.5(18.7,24.8)$ & $21.0(18.3,24.4)$ & $23.5(21.7,25.4)$ & $23.1(21.4,25.0)$ & $21.3(19.7,23.1)$ & $21.0(19.3,22.8)$ \\
\hline 10 & $19.0(17.3,20.8)$ & $22.3(19.1,26.5)$ & $20.7(17.8,24.1)$ & $20.7(18.0,24.1)$ & $22.1(19.0,25.8)$ & $21.7(18.6,25.7)$ & $24.2(22.2,26.3)$ & $23.8(21.8,26.0)$ & $21.9(20.1,23.9)$ & $21.6(19.8,23.7)$ \\
\hline 25 & $19.2(17.4,21.1)$ & $23.4(19.6,28.5)$ & $21.3(18.1,25.1)$ & $21.6(19.3,26.8)$ & $22.7(19.3,26.8)$ & $22.5(19.0,27.2)$ & $24.8(22.7,27.1)$ & $24.6(22.4,27.1)$ & $22.6(20.5,24.7)$ & $22.4(20.3,24.8)$ \\
\hline 50 & $19.3(17.5,21.3)$ & $24.1(19.9,29.9)$ & $21.7(18.3,25.8)$ & $22.2(18.7,26.8)$ & $23.1(19.4,27.5)$ & $23.0(19.1,28.3)$ & $25.2(22.9,27.7)$ & $25.1(22.6,27.9)$ & $22.9(20.8,25.2)$ & $22.9(20.5,25.5)$ \\
\hline 100 & $19.4(17.5,21.4)$ & $24.8(20.2,31.3)$ & $22.0(18.4,26.3)$ & $22.7(18.9,27.8)$ & $23.3(19.5,28.0)$ & $23.4(19.3,29.2)$ & $25.5(23.1,28.1)$ & $25.5(22.9,28.5)$ & $23.2(21.0,25.6)$ & $23.3(20.8,26.1)$ \\
\hline
\end{tabular}

